\title{
TESTING FOR THE FUNDAMENTAL DETERMINANTS OF THE LONG-RUN \\ REAL EXCHANGE RATE: THE \\ CASE OF TAIWAN
}

\author{
Hsiu-Ling Wu
}

Working Paper 5787

\author{
NATIONAL BUREAU OF ECONOMIC RESEARCH \\ 1050 Massachusetts Avenue \\ Cambridge, MA 02138 \\ October 1996
}

This paper was presented at the NBER East Asian Seminar on Economics. This work is part of the NBER's project on International Capital Flows and the author is grateful for support from the Center for International Political Economy. The author is thankful to Yueh-Fang Ho for research assistance, Nancy Zigmund for editorial improvements. Any opinions expressed are those of the author and not those of the National Bureau of Economic Research.

(C) 1996 by Hsiu-Ling Wu. All rights reserved. Short sections of text, not to exceed two paragraphs, may be quoted without explicit permission provided that full credit, including $\mathbb{C}$ notice, is given to the source. 


\title{
TESTING FOR THE FUNDAMENTAL DETERMINANTS OF THE LONG-RUN \\ REAL EXCHANGE RATE: THE \\ CASE OF TAIWAN
}

\begin{abstract}
Three things have been suggested in this paper regarding the real exchange rate movements of the Taiwanese dollar with respect to the US dollar. First, the real exchange rates between the Taiwanese and the US dollar did not move as PPP predicts by cointegration test and impulse response function analysis. Also, through the analyses of impulse response functions, innovation in nominal exchange rate, domestic and foreign prices results in permanent changes in the real exchange rate. Finally, in the long-run, differential productivity growth between the traded and nontraded goods and the changes in relative unit labor cost can lead to the changes in the real exchange rates.
\end{abstract}

Hsiu-Ling Wu

Chung-Hua Institution for Economic Research

75 Chang-Hsing Street

Taipei

TAIWAN

hlwu@rs930.cier.edu.tw 


\section{Introduction}

The real exchange rate between two countries' currencies has been recognized as a key measure of the prices of foreign goods relative to domestic goods in those countries. Since the real exchange rate reveals the relative competitiveness of the exported goods from two economies, it is desirable to characterize the behavior of the real exchange rate and test for its fundamental determinants.

The behavior of the real exchange rate is intimately related to the behavior of deviations from purchasing power parity (PPP). According to PPP theory, nominal exchange rates adjust to offset changes in relative prices, so the real exchange rate should remain at a constant value. However, there is widespread agreement that substantial deviations from PPP have occurred since the abandonment of the Bretton Woods System. ${ }^{1}$ That is, there is no equilibrium value to which the real exchange rate tends to return. In empirical tests, many authors indeed cannot reject the hypothesis that real exchange rates follow a random walk process. ${ }^{2}$ Thus changes in the real exchange rate are considered permanent. Some kinds of real disturbances are believed to upset the relationship between the nominal exchange rate and relative price levels as postulated by PPP so that the behavior of real exchange rates is found to be inconsistent with PPP.

To assess the fundamental factors determining the behavior of the real exchange rate, a number of studies have considered productivity differentials between the nontraded and traded sectors of economies as a prime cause of permanent changes in real exchange rate. According to Balassa (1964), if productivity in the domestic traded goods sector grows more rapidly than productivity in the non-traded goods sector,

\footnotetext{
${ }^{1}$ There are two versions of PPP theory, absolute PPP and relative PPP. Absolute PPP theory, which relies on the law of one price, states that the general level of prices, when converted to a common currency, will be the same in every country $(\mathrm{P}=\mathrm{EP} *)$. Absolute PPP holds only if two price levels are computed in the same way as weighted tradeable prices in a competitive world market with no transportation costs or trade barriers. Therefore, absolute PPP can hardly be expected to hold in a real world. Relative PPP theory says that the rate of change in nominal exchange rate is equal to the domestic inflation rate minus the foreign inflation rate. The validity of relative PPP is often tested by implementing the regression analysis of $\ln \mathrm{P}=\ln \mathrm{E}+\ln \mathrm{P}^{*}+\mathrm{e}$.

${ }^{2}$ For instance, see Frenkel (1981), Hakkio (1986) and Mark (1990).
} 
under the assumption of equalization in wages across sectors, the relative price between traded and non-traded goods has to fall. Since the prices of traded goods are equalized between countries through international arbitrage, the general price level will rise at home. It follows that the real exchange rate will appreciate. Hsieh's (1982) work uses time-series data of Germany and Japan versus their respective major trading partner to study the relationship between movements in real exchange rates and productivity growth differentials in the traded and non-traded sectors. His study has provided strong evidence supporting the idea that productivity differentials are useful in explaining the movements in real exchange rates.

Marston (1987) investigated the effects of productivity growth differentials between the United States and Japan on the alternative real exchange rates between the yen and dollar. Since real exchange rates based on alternative price series can diverge when there are shifts in supply factors within a country, Marston considered different expressions of real exchange rates to evaluate the relative competitiveness of the two economies. For instance, from 1973 to 1983 the yen appreciated in terms of the GDP deflator by 0.3 percent, while the real exchange rate expressed in terms of the GDP deflator for traded goods alone depreciated 26.7 percent. This result suggests that real exchange rates based on different price indexes may lead to very different conclusions. Thus, it is desirable to find out what can account for the divergence between two real exchange rate series. According to Marston, the differential movement between any two real exchange rates results from relative unit labor cost changes in traded sectors at home and in the foreign country and unit labor cost changes in traded sectors of each country relative to the non-traded sectors. Since sectoral wage trends are similar in the US and Japan, it is relative productivity movements in traded and non-traded sectors which explain the difference of movements in real exchange rates.

In the real world, it is observed that in Japan, productivity growth in the traded sector was 73.2 percent greater than in the non-traded sector, and productivity in the US traded sector grew only 13.2 percent faster than in its non-traded sector during the 
1973-1983 period. The markedly higher productivity growth differential together with the lack of any substantial decline in nominal wages in the US, therefore, reduced the relative competitiveness of US exports.

The empirical purpose of this article is to investigate the factors that determine long-run movements of the real exchange rate of the New Taiwan dollar (NT dollar) against the US dollar. The recent developments in time series analysis have provided new ways of analyzing the long-run relationships for our purpose. Particularly, the theory of cointegration provides a means of establishing whether a long-run relationship exists between economic variables. Since testing for cointegration among economic variables seems to have become a standard method of assessing the empirical support for the equilibrium of economic behavior, we wish to test the behavior of the real exchange rate by applying the principle of cointegration. This paper is not limited to a test of the theory of purchasing power parity. It will also test for the role of the fundamental factor - productivity, which has been identified in several papers as determining the movements in real exchange rates.

The organization of the article is as follows. In Section II, I give an introduction on the evolution of exchange rate management in Taiwan. In Section III, the movements of real exchange rates, nominal exchange rates and relative price levels are briefly discussed. In Section IV, analysis using cointegration approaches is discussed. Section $\mathrm{V}$ tests for the long-run properties of real exchange rate movements. In Section VI, we evaluate the effects of changes in nominal exchange rates, and foreign and domestic price levels on the real exchange rate. In Section VII, we look into the relationship of real exchange rate change and the relative productivity growth of traded and non-traded sectors. Section VIII summarizes the overall findings of the paper.

\section{The Evolution of Exchange Rate Management in Taiwan}

Before January 1979, the New Taiwan dollar (NT dollar) was tied to the US dollar. This was primarily because the US was Taiwan's most important trading 
partner and most Taiwanese international contracts were denominated in US dollars. The pegging system helped reduce exporters' uncertainties in international trade. However, the system had some drawbacks. It was commonly recognized that the domestic economy would become more vulnerable to external disturbances. For instance, Taiwanese exports would be less competitive in the US market as the US dollar soared against other currencies.

With the promulgation of the revised Foreign Exchange Regulation, a foreign exchange market was established on February 1, 1979, and a managed floating rate system was introduced in Taiwan. When adopting the new exchange rate system, the exchange rate of the NT dollar against the US dollar was at first fixed by an ad hoc committee comprising five representatives from five appointed banks ${ }^{3}$ and one representative from the central bank. From March 1980, the central bank delegated the other members of the committee to fix the daily spot and forward exchange rate. The ad hoc committee took into account the demand and supply of foreign exchange as well as the real effective exchange rate index of the NT dollar when fixing the spot rate of the NT dollar against the US dollar. ${ }^{4}$

After trial and error, the mechanism for exchange rate determination evolved in 1982 into a form which was based on the weighted average rate of inter-bank transactions in US dollars on the previous business day. ${ }^{5}$ Daily fluctuations of the inter-bank rate have been only allowed to float within a $2.25 \%$ range from the weighted average rates on all interbank currency exchange transactions, which were established daily by five representatives from five appointed banks. To maintain an orderly foreign exchange market, the central bank also intervened on many occasions

${ }^{3}$ They are the Bank of Taiwan, the International Commercial Bank of China, the First Commercial Bank of Taiwan, the Chang-Hwa Commercial Bank of Taiwan, and the Hwa-nan Commercial Bank.

4 For example, the devaluation of the NT dollar against the US dollar by $4.63 \%$ in August 1981 was to make up the loss of competitiveness resulting from real effective overvaluation since the US dollar was strengthening against the other currencies.

5 Taiwan has mechanisms for managing exchange rates in both the interbank and customer-bank foreign exchange markets. The interbank market consists of foreign exchange transactions between banks. Customer-bank transactions refer to individuals changing currency with a designated foreign exchange bank. It is the interbank market that has played a pivotal role in setting exchange rate. 
by buying and selling the US dollar in the inter-bank market.

As was widely noticed, because of the huge trade surplus and the considerable influx of private short-term capital, the supply of foreign exchange far exceeded the demand in Taiwan during the mid-1980s. As a result, the exchange rate of the NT dollar against the US dollar appreciated steadily from 1986 to 1989. The NT dollar appreciated against the US dollar by 12.25 percent over $1986,24.34$ percent over $1987,1.35 \%$ over 1988 , and $7.13 \%$ over 1989 . During this period, the central bank's intervention in the foreign exchange rate involved direct buying and selling of foreign exchange in the interbank market to stabilize wide fluctuations in the value of the NT dollar that otherwise have would occurred, since officials in the central bank believe that the exchange rate should be adjusted in a smooth way rather than a substantial one-shot appreciation. This intervention, however, has two additional effects. Firstly, it raises the level of foreign exchange reserves. Secondly, it generates some expansionary effect on the local money supply. Hence the central bank has introduced a series of measures to liberalize foreign exchange controls since 1986 to address the external disequilibrium. It has also applied other policies such as increasing in the reserve requirements for savings deposits and issuing bonds and treasury bills to banks to limit credit expansion.

In addition to liberalizing in Taiwanese capital controls, the central bank also changed the foreign exchange rate trading system in 1989 to accelerate economic liberalization and internationalization in Taiwan. The bank abolished the former system, which used the weighted average rate of interbank transactions as the central rate on the next business day and had set limits on daily fluctuations. According to the central bank, after some additional modifications are made, the structure of the foreign exchange market in Taiwan will be more complete and concrete, since its operating methods will be similar to those prevailing in developed countries. This should make the exchange rate for the NT dollar more flexible and it will reflect its actual value in the market. 


\section{The Movements of the Real Exchange Rate}

Exchange rate changes can be measured in nominal or real terms. A measure in real terms against one currency provides a better measure of relative competitiveness than do measures in nominal ferms. Consider the real exchange rate $(R)$ defined in terms of nominal exchange rate $(\mathrm{E})$ adjusted for relative price levels $\left(\mathrm{P}^{*} / \mathrm{P}\right)$, that is $\mathrm{R}=\mathrm{EP} * / \mathrm{P}$. In our case, the nominal exchange rate is defined as the NT $\$$ price of US $\$ 1$, so that an increase in E indicates a depreciation of the NT\$; * denotes the foreign economy (US). A rise in real exchange rate (that is, a real depreciation of NT\$) corresponds to a fall in the purchasing power of domestic currency for foreign products. This change in relative purchasing power occurs because the NT\$ prices of US products rise relative to those of Taiwanese products.

Figure 1 shows the fluctuations of the nominal exchange rates, relative price levels and real exchange rates between 1985 and 1995. The nominal exchange rate appreciated by 34.35 percent from 1985 to 1989 . This was matched by a 22.16 percent real appreciation during the same period. Thus, it seems that both nominal exchange rate appreciation and the inflation differentials between domestic and foreign countries were responsible for changes in the real exchange rates, though the real exchange rate movements were mainly caused by the nominal appreciation of the NT dollar during 1985-1989 period. The upward movements of the relative price levels offset some effects of the nominal appreciation of the NT dollar against the US dollar so that the magnitude of real appreciation was smaller than that of the nominal exchange rates.

As shown in Figure 1, the nominal exchange rates have started to fluctuate in a more stable range between NT27.5:US\$1 and NT25.5:US\$1 since 1989. During the same period, fluctuations of the real exchange rate were also not as volatile as in the 1985-1989 period. However, during the period from 1989 to 1995, it appeared that the real exchange rate movements were dominated more by inflation differentials between Taiwan and the US than the nominal exchange rate changes. Hence, in the following sections I will evaluate aspects of the real exchange rate behavior by analyzing (1) the 
extent to which the real exchange rates revert, in the long run, toward the purchasing power parity; (2) the persistent effect of a nominal exchange rate and domestic and foreign price level adjustment on the real exchange rate; and (3) the equilibrium relationship between the real exchange rate and differentials of productivity growth between traded and non-traded goods.

\section{VAR modeling and the Cointegration Approach}

This section discusses the cointegration approach, which provides not only an estimation methodology but also explicit procedures for testing the long-run relationship among variables which is suggested by economic theory.

According to the Granger Representation Theorem, if a $\mathrm{p}^{* 1}$ vector, Xt, generated by $(1-L) X_{t}=d+c(L) e_{t}$, is cointegrated, then there exists a vector autoregressive (VAR), an error correction, as well as a moving average (MA) representation of $\mathrm{Xt}^{6} \mathrm{~A}$ set of variables, $\mathrm{Xt}$, which is cointegrated, refers to the existence of long-run equilibrium relationships among economic variables. That is, though each series may be nonstationary, there may exist stationary linear combinations of the variables. The basic idea is that individual economic time-series variables wander considerably, but certain linear combinations of the series do not move too far apart from each other. In economic terms, there is a long-run relationship among variables.

The most common test for cointegration is the two-step procedure of Engle and Granger (1987) which performs the tests in a univariate setup. The first step is to fit the cointegrating regression, which is the OLS estimation of the static model. Second, a unit root test is conducted on the estimated residuals. To test for cointegration is just to test for the presence of a unit root in the residuals of the cointegrating regression. If the null of a unit root is rejected, then the null of no cointegration is also rejected. However, the long-run parameter of the cointegrating vector estimated from this

\footnotetext{
${ }^{6}$ See Engle and Granger, 1987.
} 
approach can be severely biased in finite samples. An improved procedure for testing for cointegration, allowing for more than one cointegration vector, is suggested in Johansen (1988) and Johansen and Juselius (1990).

Following Johansen and Juselius (1990), let the p variables under scrutiny follow a vector autoregression of order $k(\operatorname{VAR}(k))$ as below

$$
X_{t}=\mu+\Pi_{1} X_{t-1}+\ldots \ldots \Pi_{k} X_{t-k}+\varepsilon_{t} \quad(\mathrm{t}=1 \ldots \ldots \mathrm{T})
$$

where $\varepsilon_{1} \ldots \ldots \varepsilon_{1}$ are innovations of this process and are assumed to be drawn from a pdimensional i.i.d. Gaussian distributions with covariance $\Gamma$ and $X_{-k+1}, \ldots \ldots . . . X_{0}$ are fixed. Let $\Delta$ represent the first difference operator. The equation can be reparameterized into the equivalent form presented below

$$
\Delta X_{1}=\mu+\Pi X_{t-k}+\sum_{i=1}^{k-1} I_{i} \Delta X_{t-i}+\varepsilon_{\imath}, \quad \mathrm{t}=1,2,3 \ldots \ldots
$$

where $I_{i}=-I+\sum_{j=1}^{i} \Pi_{j} \quad$ for $\mathrm{i}=1 \ldots \ldots \mathrm{k}-1, \quad \Pi=I+\sum_{1}^{k} \Pi_{j}$

The coefficient matrix $\Pi$ contains information about the long-run relationship among variables. Since $\varepsilon$, is stationary, the number of ranks for matrix $\Pi$ determines how many linear combinations of $\mathrm{X}_{\mathrm{t}}$ are stationary. If $0<\operatorname{Rank}(\mathrm{P})=\mathrm{r}<\mathrm{p}$, there exist $\mathrm{r}$ cointegrating vectors that make the linear combinations of $X_{1}$ become stationary. In that case, $\Pi$ can be factored as $\alpha \beta^{\prime}$, with $\alpha$ and $\beta$ being matrices. $\beta$ is a cointegrating vector that has the property that $\beta^{\prime} \mathrm{X}_{1}$ is stationary even though $\mathrm{X}_{1}$ itself is non-stationary. $\alpha$ then contains the adjustment parameters.

Based on the unrestricted estimation which is parameterized in terms of level and differences, Johansen (1988) proposed likelihood ratio statistics for testing the number of cointegrating vectors. First, we must solve the eigenvalues of $\left|\lambda S_{k k}-S_{k 0} S_{00}{ }^{-1} S_{0 k}\right|=0$, where $S_{00}$ is the moment matrix of the residuals from the ordinary least squares regression of $\Delta X_{t}$ on $\Delta X_{t-1} \ldots . . \Delta X_{t-k+1} ; S_{k k}$ is the residual moment matrix from the ordinary least squares regression of $\Delta X_{1-k}$ on $\Delta X_{1-1} \ldots \ldots$ $\Delta X_{t-k+1} ;$ and $S_{0 \mathrm{k}}$ is the cross-product moment matrix. The cointegrating vector, $\beta$, is solved out as the eigenvectors associated with the $r$ largest statistically significant eigenvalues are derived using two test statistics, "maximum eigenvalue statistics" and 
"trace statistics." The first statistic tests the hypothesis that there are $\mathrm{r}=\mathrm{s}$ cointegrating vectors against the alternative of $\mathrm{r}=\mathrm{s}+1$ by calculating the maximum likelihood test statistics as $-\mathrm{T} \ln \left(1-\lambda_{s+1}\right)$, where $\mathrm{T}$ is the sample size and $\lambda_{s+1}$ is an estimated eigenvalue. The second statistic tests the hypothesis that there exist at most, $r$ cointegrating vectors. It is performed by calculating so-called trace statistics: $-T \sum_{i=r+1}^{p} \ln \left(1-\lambda_{i}\right)$, where $\lambda_{r+1} \ldots \ldots \lambda_{p}$ are the estimated p-r smallest eigenvalues. Given the number of cointegrating relations, with or without a linear trend, the data can also be analyzed by another reduced rank regression by calculating the test statistics $-T \sum_{i=r+1}^{P} \ln \left\{\left(1-\lambda_{i}{ }^{*}\right) /\left(1-\lambda_{i}\right)\right\}$, where $\lambda_{i}^{*}$ are eigenvalues obtained from cointegration analysis assuming there is no linear trend.

\section{Real Exchange Rate in the Long Run}

In this section, I investigate the behavior of the real exchange rate with cointegration methods to see if its long-run movement is consistent with the implications of PPP theory. The relative PPP theory asserts that the rate of change in the nominal exchange rate is equal to the domestic inflation minus the foreign inflation rate. This implies that when the nominal exchange rate goes up or down, the relative price levels will adjust continuously in order to maintain the real exchange rate close to its long-run equilibrium level. The equation for the relative PPP theory may be rearranged to produce an expression for the change in the real exchange rate, so that the real exchange rate change should equal zero.

To investigate if there are deviations of the real exchange rate away from its equilibrium value, I test for cointegration relations among changes in nominal exchange rates, and domestic and foreign price levels without imposing any proportionality and symmetry restrictions, instead of checking the stochastic process of the real exchange rate series by a unit root test. ${ }^{7} \mathrm{I}$ do this because of the suggestion

\footnotetext{
7 If the series of real exchange rate is stationary, i.e., the series contains no unit root, then it tends to fluctuate around the mean in the long run. Non-stationary series, however, wander widely and rarely
} 
of Cheung and Lai (1993) that measurement errors in price variables would cause violations of the symmetry restrictions of the absolute PPP theory and thus cause us to erroneously accept the hypothesis of a non-stationary real exchange rate. ${ }^{8}$

The estimating model for such a version may be empirically formulated as: $\ln \mathrm{E}=\mathrm{a}_{0}+\mathrm{a}_{1} \ln \mathrm{P}+\mathrm{a}_{2} \ln \mathrm{P}^{*}+\mathrm{u}$, where $\mathrm{E}$ denotes the bilateral nominal exchange rate, $\mathrm{P}$ is the domestic price level, $\mathrm{P}^{*}$ stands for the foreign price level and $\mathrm{u}$ is the error term. Testing for a cointegrated relationship among a set of variables is done in two steps. The first step is to verify the order of integration of the variables. Second, cointegration tests are conducted upon variables with compatible properties. The stochastic properties of variables can be investigated by applying the Augmented Dickey-Fuller (ADF) test. The hypothesis that the variable Xt is a I(1) series is tested by conducting a regression on the following equation: 9

$$
\Delta X_{t}=\mu+\beta t+\alpha X_{t-1}+\sum_{i}^{P} K_{i} \Delta X_{t-i}+\varepsilon_{t}
$$

where $\mathrm{Xt}$ stands for variables appearing in the equation; $\mathrm{p}$ is the number of lags chosen to ensure that the estimated residuals, $\varepsilon$, are approximately white noise; $\mu$ is the constant term; and $\mathrm{t}$ is a time trend. If we cannot reject the hypothesis that $\mathrm{Xt}$ is a unit root process, then the unit root test is applied to $\Delta X_{,} . \mathrm{Xt}$ is an $\mathrm{I}(1)$ series only when $\Delta X$, is not a unit root process.

Monthly observations from January 1981 through September 1995 were used for the empirical study. The nominal exchange rate series, which are monthly average rates, are collected from Financial Statistics Monthly (Taiwan District) published by the Central Bank of Taiwan. The relevant price indexes of Taiwan are also from

return to an earlier value. Thus, real exchange rates change, and this change quantifies deviations from PPP.

8 Since observed prices serie are imperfect proxies for the theoretical price variables, some measurement errors exist. These measurement errors can be associated with international differences in consumption patterns, variations in product quality and differences between listed and transaction prices. If symmetry and proportionality conditions are not consistent with the data, the imposition of these conditions can bias PPP tests on real exchange rate towards finding non-stationarity. In such a case, a finding of a nonstationary real exchange rate can indicate a violation of the symmetry or proportionality restrictions and still be consistent with PPP theory.

${ }^{9}$ See Dickey and Fuller (1979 and 1981). 
Financial Statistics Monthly, whereas the US data are from the International Financial Statistics tape from the IMF.

The results of the unit root test are reported in Table 1. The autoregressive lag lengths are chosen to be shortest for the residuals from the regression, which the BoxLjung Q-statistic suggests are white noise. As shown in Table 1, the null hypothesis of a nonstationary exchange rate cannot be rejected for the log levels of all the variables. The unit root tests of the first difference of the log of the variables lead us to reject the unit root null hypotheses at the $95 \%$ significance level, since the ADF statistics are significantly negative. In summary, the tests indicate that the variables of nominal exchange rates and domestic and foreign price levels are compatibly integrated of order one and these variables are suitable for the cointegration test.

To test for the cointegration relationship, the Johansen approach of the cointegration test was performed in the VAR framework. In order to avoid any bias of the regression result by measurement errors, the cointegrating regression was considered without imposition of symmetry and proportionality restrictions. Table 2 reports the values of the Johansen test statistics, indicating that changes in nominal bilateral exchange rates are not cointegrated with those in domestic and foreign price levels, when either WPI(Wholesale Price Index) or CPI(Consumer Price Index) are used. The results appear to suggest that the simple notion of the PPP relationship did not hold for the real exchange rate between the Taiwanese and the US currencies during the period under review. This implies that the nominal bilateral exchange rate for the Taiwanese dollar vis-a-vis the US dollar and the corresponding price levels drifted apart from each other following shocks to the Taiwanese economy. More generally, this indicates that movements in real exchange rates can be regarded as being permanent and the real exchange rate should not be expected to return to the equilibrium PPP value. 


\section{Impulse-Response Analysis}

Our inability to reject the null hypothesis of a cointegration relationship between the nominal exchange rate and foreign and domestic price levels implies that shocks to the real exchange rate are so persistent that it does not return to the long-run value, as purchasing power parity theory predicts. Because the real exchange rates are constructed by the nominal exchange rates and relative price levels, the variability in real exchange rates can be dominated by either the nominal exchange rates or relative price level changes. In this section, we investigate the extent to which the nominal exchange rate and foreign and domestic price level changes affect the real exchange rate through an analysis of their impulse response functions.

For this purpose, we estimated an unrestricted vector autoregression (VAR) consisting of the first difference in the logarithms of the nominal exchange rate and domestic and foreign price levels:

$$
A(L) X,=\mu,
$$

where $X_{1}=\left(\Delta P_{1}, \Delta E_{\imath}, \Delta P_{\imath}{ }^{*}\right) ; A(L)=\sum_{j=0}^{k} A_{j} L^{j} ;$ and $\mathrm{A}_{0}=\mathrm{I}$.

Akaike's information criterion was employed to select the lag length of the vector autoregressive system. Inverting $\mathrm{A}(\mathrm{L})$, we get the moving average representation $X_{1}=A(L)^{-1} \mu_{t}$. To evaluate the dynamic response of the variables in $\mathrm{Xt}$ to an innovation in $\Delta P_{1}, \Delta E_{t}, \Delta P_{t}^{*}, \mu_{\mathrm{t}}$ is orthogonalized by means of a Choleski factorization of $\Omega$. Let $\varepsilon_{t}=\mathrm{B} \mu_{t}$, with B chosen to be a lower triangular matrix such that $\mathrm{B} \Omega \mathrm{B}^{\star}=\mathrm{I}$. I is a diagonal matrix. Thus we can write $\mathrm{Xt}=\mathrm{C}(\mathrm{L}) \varepsilon_{1}$, where

$$
\mathrm{C}(\mathrm{L})=\mathrm{A}(\mathrm{L})^{-1} \mathrm{~B}(\mathrm{~L})^{-1}=\left[\begin{array}{lll}
C_{11}(L) & C_{12}(L) & C_{13}(L) \\
C_{21}(L) & C_{22}(L) & C_{23}(L) \\
C_{31}(L) & C_{32}(L) & C_{33}(L)
\end{array}\right]
$$

The change in $P, E$, and $P^{*}$ responding to a unit shock to $P$ is given by $C_{11}(L), C_{21}(L)$, and $\mathrm{C}_{31}(\mathrm{~L})$ respectively. Similarly, the changes in $\mathrm{P}, \mathrm{E}$, and $\mathrm{P}^{*}$ responding to innovations in $E$ and $P^{*}$ are presented by $C_{12}(L), C_{22}(L)$, and $C_{32}(L)$, and $C_{13}(L), C_{23}(L)$, 
and $\mathrm{C}_{33}(\mathrm{~L})$. Therefore the implied change in $\mathrm{R}$ following shocks to $\mathrm{P}, \mathrm{E}$ and $\mathrm{P*}$ is ($\left.\mathrm{C}_{11}+\mathrm{C}_{21}+\mathrm{C}_{31}\right),\left(-\mathrm{C}_{12}+\mathrm{C}_{22}+\mathrm{C}_{32}\right)$, and $\left(-\mathrm{C}_{13}+\mathrm{C}_{23}+\mathrm{C}_{33}\right)$, respectively. Notice that if purchasing power parity theory held, $\left(-\mathrm{C}_{12}+\mathrm{C}_{22}+\mathrm{C}_{32}\right)+\left(-\mathrm{C}_{13}+\mathrm{C}_{23}+\mathrm{C}_{33}\right)-\left(-\mathrm{C}_{11}+\mathrm{C}_{21}+\mathrm{C}_{31}\right)$ would be identically zero.

Table 3 shows the cumulative impulse response function of $\Delta P, \Delta E$ and $\Delta P{ }^{*}$, together with the implied impulse response function for $\Delta R .{ }^{10}$ From this table it is seen that a unit of innovation in the domestic price level generally leads to a 1.77 percent increase in the domestic price level. Relatively small changes in the domestic price level follow shocks in nominal exchange rate and foreign price level. A unit innovation in nominal exchange rate is followed by an approximately 1.09 percent increase in the nominal exchange rate. A one percent shock in domestic and foreign price levels leads to a 0.12 percent increase and a 0.475 percent decrease in the value of the nominal exchange rate, respectively. A unit shock to the foreign price level causes a greater change in foreign prices than do innovations in the domestic price level and the nominal exchange rate. In Table 3, we also report the change in the real exchange rate following a unit innovation in $\Delta P, \Delta E$ and $\Delta P^{*}$. This cumulative change is near minus one for a shock to the domestic price level and one for a shock to the foreign price level. The estimates indicate that each unit change in the domestic and foreign price level is followed by a unit increase in the real exchange rate. The cumulative change of innovations in the nominal exchange rate of 0.804 percent suggests that a percentage change in the nominal exchange rate will induce a 0.804 percent change in the real exchange rate.

In summary, there is again no evidence to support the idea that there is a longrun relationship between nominal exchange rate and relative price levels, as postulated by PPP theory. Innovations in nominal exchange rate changes are followed by permanent changes in real exchange rate. It also appears that innovations in domestic and foreign price levels lead to permanent change in the real exchange rate.

10 The price level considered here is based on WPI. 


\section{Real Exchange Rate Movements and Productivity Growth}

The earlier analysis suggests that there is no systematic tendency for the real exchange rate to revert to a constant equilibrium level after a shock. Permanent shifts in the real exchange rate can result from permanent changes in nominal exchange rate and in domestic and foreign price levels. In this section, a popular model of real exchange rate determination as proposed by Balassa (1964) is called upon to attest to the validation of the observations. The Balassa proposition suggests that when productivity advances more rapidly in a country's traded goods sector than its nontraded sector, that is, when real shocks cause permanent changes in the relative price of traded to non-traded goods, the relative price levels between the domestic and foreign countries are subject to change. Hence, the underlying equilibrium real exchange rate is also subject to change. However, this is not the whole story, in our view. As the nominal exchange rate changes, the relative labor unit costs would change when both the domestic and foreign labor cost are computed in the same currency. In such a way, nominal exchange rate changes induce differences in the growth rate of unit labor costs between the two countries, and then cause the real exchange rate to change. In the following section, we will investigate the movement of real exchange rate based on the model of productivity differentials. First, we briefly present the basic model used to explain long-run changes in the real exchange rate.

According to Hsieh (1982), let $\mathrm{P}$ and $\mathrm{P}^{*}$ denote the domestic and foreign price indices, which are defined as the weighted averages of the prices in the traded and non-traded goods sectors.

$$
P=\left(P_{1}\right)^{1-\alpha}\left(P_{n}\right)^{\alpha}
$$

$P^{*}=\left(P_{1}\right)^{1-\beta}\left(P_{n}\right)^{\beta}$, where $\alpha$ and $\beta$ are constant weights between zero and unity.

Then the real exchange rate can be expressed as:

$\mathrm{EP}^{*} / \mathrm{P}=E\left(\frac{P_{n}^{*}}{P_{t}^{*}}\right)^{\beta}\left(\frac{P_{n}}{P_{t}}\right)^{-\alpha}\left(\frac{P_{t}^{*}}{P_{t}}\right)$

Assuming constant returns to scale and a fixed supply of labor at home and abroad, with labor being the only factor of production, and free mobility of labor between 
sectors, the same nominal wage $W$ will prevail in both sectors. $A_{t}$ and $A_{n}$ denote the average productivity of labor in the traded and non-traded goods sectors respectively. Perfection competition among producers in both sectors ensures that prices equate average production cost:

$P_{t}=W / A_{t}$

$P_{n}=W / A_{n}$

$\mathrm{P}_{\mathrm{t}}^{*}=\mathrm{W}^{*} / \mathrm{A}_{\mathrm{t}}{ }^{*}$

$P_{n}^{*}=W^{*} / A_{n}^{*}$

Substituting (2) into (1), one obtains:

$$
R=E\left(\frac{A_{n}^{*}}{A_{t}^{*}}\right)^{-\beta}\left(\frac{A_{n}}{A_{t}}\right)^{\alpha}\left(\frac{\frac{W^{*}}{A_{t}^{*}}}{\frac{W}{A_{t}}}\right)
$$

Expressing (3) in natural logarithm, one obtains:

$$
\ln R=\alpha\left(\ln A_{n}-\ln A_{\imath}\right)-\beta\left(\ln A_{n}^{*}-\ln A_{,}^{*}\right)+\ln E+\ln \left(\frac{W^{*}}{A_{t}^{*}}\right)-\ln \left(\frac{W}{A_{l}}\right)
$$

The theory outlined above suggests that the behavior of real exchange rate could reflect productivity growth. The first term on the right hand side is the difference in growth rate of labor productivity between domestic non-traded and traded sectors. The second term is the difference between the same two foreign sectors. The third term on the right-hand side can be considered the difference in the growth rate of unit labor costs between two countries.

Hsieh's (1982) work uses time-series data to estimate Equation (4) to find supporting evidence for the idea that productivity differentials between sectors can explain the behavior of the real exchange rate series. However, as there is a consensus among researchers that many economic time series have no tendency to return to an equilibrium value, we have little confidence that Equation (4) provides a good approximation of the relationship among variables without a formal test of the nature of the data set. If a unit root exists in any one of the series, the statistical interpretation and properties of the least square estimates for the model may not be valid. Thus, we 
will consider the time-series behavior of each series individually, and then investigate the possibility of a long-run equilibrium among the series.

As discussed, Equation (4) provides a framework for the analysis of the real exchange rate. As far as the variables used in the model are concerned, the traded sector is the manufacturing industries. Labor productivity in manufacturing is calculated by dividing the real output of manufacturing by the number of employees and work hours. The non-traded sector then is defined as the service sector only. The labor productivity of this sector is computed in a similar way by dividing the real output of the service sector by the number of workers in the service sector and the average working hours. The data on real output in manufacturing and services in Taiwan are obtained from the NIAQ data bank. The data on number of workers, average working hours and the wage rate are taken from the WAGE data bank. For the US, real output information are collected from the US data bank, and the remaining elements are taken from the NIPA data bank. All these data banks are accessible in the AREMOS/UNIX economic data base system maintained by the Education Ministry of Taiwan.

First we consider the stochastic properties of the series of differences of changes in productivity between traded sectors and non-traded sectors at home and abroad, and the differences of changes in unit labor cost. According to the ADF-test statistic, for all the series examined, the hypothesis of a unit root could not be rejected at the $95 \%$ significance level. Unit root tests were applied also to the first-differenced series, and the I(1) null hypothesis could be rejected for all the series, as shown in Table 4. These findings suggest that the levels of series are I(1). The Johansen cointegration approach is next performed in the VAR framework. First, different values of the lag length $k=1$ to 8 are considered. In most cases, a lag of $k=4$ is required to remove serial correlation in the residuals. The test for is there a linear trend in the nonstationary part of the process is performed by $-T \sum_{i=r+1}^{p} \ln \left\{\left(1-\lambda_{i}^{*}\right) /\left(1-\lambda_{i}\right)\right\}$, where $\lambda_{i}^{*}$ are eigenvalues obtained from cointegration analysis assuming no trend. Since with a linear trend is 
confirmed, we proceed with the Johansen procedure. Table 5 reports the values of the Johansen test statistic for the numbers of cointegrating vectors. In the case under consideration, the hypothesis of no cointegrating vector $(r=0)$ can be rejected at the 95\% level, indicating that the series in Xt are cointegrated as suggested by the model. The (normalized) estimates of the equilibrium relation are given by $(1,1.16,-1.01$, $0.53506) . \alpha$ is found to be $(-0.00292,-0.19305,0.3146,-0.4048)$, the average speed of adjustment toward the estimated equilibrium state. In our case, the coefficients are significantly differently from zero with the correct signs. The results show that improvements in the productivity of the non-trade sector at home lead to long-run depreciation of the real exchange rate, a result which is the same as the Balassa (1964) analysis. Conversely, faster productivity growth in the non-traded sector abroad results in an appreciation of the real exchange rate. Furthermore, the difference in unit labor cost will also cause the real exchange rate to rise.

It should be noted that a fundamental model-building point is the assumption of perfect competition. Under this assumption, prices are set equal to the marginal cost, and the prices of the traded goods do not violate the law of one price. Since models of international trade have increasingly emphasized how traded goods' prices are affected by market structures that deviate from perfect competition, we would also like to relax this assumption and see how the equilibrium relationship changes.

Relaxing the assumption of perfect competition in traded good sectors only, we can see that the firms will then set the price at which the marginal revenue equates marginal cost. The prices of traded goods at home and abroad represent some mark-up over unit cost :

$P_{t}=\left(W / A_{t}\right)(1+m)$

$\mathrm{P}_{\mathrm{t}}{ }^{*}=\left(\mathrm{W}^{*} / \mathrm{A}_{\mathrm{t}}{ }^{*}\right)\left(1+\mathrm{m}^{*}\right)$, where $\mathrm{m}$ and $\mathrm{m}^{*}$ are domestic and foreign profit margins over costs. Profit margins vary because of the characteristics of the market structure and/or changes in the macroeconomic environments. Plugging the new price equation of traded goods into the real exchange rate expression and taking the logarithm, we obtain: 


$$
\begin{aligned}
\ln R= & (1-\beta) \ln \left(1+m^{*}\right)-(1-\alpha) \ln (1+m)+\alpha\left(\ln A_{n}-\ln A_{t}\right)-\beta\left(\ln A_{n}^{*}-\ln A_{t}^{*}\right) \\
& +\left(\ln E+\ln \left(\frac{w^{*}}{A_{t}^{*}}\right)-\ln \left(\frac{w}{A_{t}}\right)\right)
\end{aligned}
$$

Equation (5) can be interpreted as saying that, as before, the real exchange rate changes depend on the relative changes in productivity between non-traded and traded sectors at home and abroad and the difference in foreign and domestic changes in unit labor cost. At the same time, since marginal revenue is computed by taking into account the profit margins, differences in profit margins are also linked to the real exchange rate. This relationship can be justified simply because the mark-up is an important measure of the competitiveness of producers.

To model differences of mark-ups in our empirical setting, we consider a timespecific effect estimation. Since the differences of mark-ups are unobservable and might vary as demand and cost conditions change, we assume that the differences of mark-ups change over time. Thus, if the links among real exchange rates, productivity differentials between non-traded and traded sectors of two countries, and differences in unit labor cost across countries are close in the long run, the time-specific effect coefficients measure the changes in profit margin differential. As suggested in Greene (1993), ${ }^{11}$ time-specific effect can be estimated by introducing dummy variables. We assume that profit margins are adjusted once every year, and then estimate the model above including an additional 14 dummy variables. 12

The estimates of time effect are shown in Table 6. These figures suggest that the movements of mark-up differentials are increasing as the real exchange rates change. That is, in the short run, allowing for imperfection competition, the adjustments of mark-ups also have something to do with real exchange rate changes.

\footnotetext{
${ }^{11}$ See Greene (1993), chapter 16.

12 Our data spans 15 years. Fourteen dummy variables were introduced since one of the time effects must be dropped to avoid multicollinearity.
} 


\section{Conclusion}

In this paper, we set about analyzing the behavior of the real exchange rate. We found that the purchasing power parity relationship does not hold in the long run. Analyses of impulse response functions also suggest that innovations in nominal exchange rate, domestic and foreign price levels result in permanent changes in the real exchange rate. The empirical tests of the productivity differential model strongly support the hypothesis that it is differential productivity growth between the traded and the non-traded goods that leads to the observed changes in real exchange rates. Thus, if the productivity differential between the non-traded and traded sectors increases in Taiwan, then the real exchange rate will depreciate. Similarly, if the productivity differential between non-traded sector and traded sectors in the US increases, the real exchange rate will decline, implying an appreciation. In addition, real exchange rates are also influenced by differences in unit labor costs across the countries. In the short run, since firms in traded sectors can price to the market, changes in mark-up differentials over traded good prices will also have something to do with the real exchange rate movements.

The lack of the PPP is attributable to several reasons. One of them, which is emphasized in this paper, is that price differentials may reflect productivity differences. Figure 2 shows the movements of labor productivity for traded and nontraded sectors in Taiwan and the US. As shown, Taiwan's labor productivity grew faster than that of the US in both traded and nontraded sectors. However, far from expectations, the growth of Taiwan's labor productivity in the non-traded sector is faster than that in its traded sector. This yields a depreciation on average when the real exchange rate is denominated in WPI during the period under review.

According to our model, the growth rate of unit labor costs in traded sectors between two countries could also account for the real exchange rate movements. Figure 3 shows the unit labor cost changes in traded sectors in Taiwan and in the US. Obviously, the diagram exhibits a distinct divergence as the unit labor cost in Taiwan gets higher and higher and the US has a decreasing trend. The differences in the 
growth of the labor unit costs explain, to some extent, the movement of the real exchange rate of the NT dollar relative to the US dollar.

If we decompose the changes of the real exchange rate of the NT dollar relative to the US dollar, both changes in nominal exchange rate and relative price levels are responsible for the changes in the real exchange rates. The differences in labor productivity growth induce the price differentials so that real exchange rates have been pushed upward. On the other hand, since the relative wage growth in Taiwan is also increasing as the nominal exchange rates appreciate, the upward pressure on the real exchange rate is offset by wage growth movement. This yields a depreciation on average. Since nominal exchange rate and domestic and foreign price levels all appear to have an effect on the real exchange rate, this implies some degree of predictability of the real exchange rates. 


\section{References}

Balassa, B. (1964), “The Purchasing Power Parity Doctrine: A Reappraisal," Journal of Political Economy, Vol. 72, pp. 584-96.

Cheung, Y. W. and K. Lai (1993), "Long-Run Purchasing Power Parity During the Recent Float," Journal of International Economics, Vol. 34, pp. $181-92$.

Dickey, D. A. and W. A. Fuller (1979), "Distribution of the Estimators for an Autoregressive Time Series with Unit Root," Journal of the American Statistical Association, Vol. 74, pp. 427-31.

Engle, R. and C. Granger (1987), "Cointegration and Error Correction : Representation, Estimation, and Testing," Econometrica, Vol. 55, pp. $251-76$.

Frenkel, J. A. (1981), “The Collapse of Purchasing Power Parities During the 1970`s," European Economic Review, Vol. 16, pp. 145-65.

Greene, W. H. (1993), Econometric Analysis, New York: Macmillan Publishing Company.

Hakkio, C. C. (1986), "Does the Exchange Rates Follow a Random Walk? A Monte Carlo Study of Four Tests for a Random Walk," Journal of International Money and Finance, Vol. 5, pp. 211-29.

Hsieh, D. A. (1982), “The Determination of the Real Exchange Rate: the Productivity Approach," Journal of International Economics, Vol. 12 , pp. $355-62$.

Johansen, S. (1988), "Statistical Analysis of Cointegration Factors," Journal of Economic Dynamics and Control, Vol. 12, pp. 231-54.

Johansen, S. (1991), "Estimation and Hypothesis Testing of Cointegration Vectors in Gaussian Vector Regression Models," 
Econometrica, Vol. 59, pp. 1551-80.

Johansen, S. and K. Juselius (1990), "Maximum Likelihood Estimation and Inference on Cointegration-With Applications to the Demand for Money," Oxford Bulletin of Economics and Statistics Vol. 52, pp. $169-210$.

Mark, N. (1990), "Real and Nominal Exchange Rates in the Long Run : An Empirical Investigation," Journal of International Economics, Vol. 28, pp. 115-36.

Marston, R. (1987), "Real Exchange Rates and Productivity Growth in the United States and Japan," in Sven W. Arndt and J. David Richardson, eds., Real-Financial Linkages among Open Economies: An Overview, Cambridge : MIT Press.

Pippenger, M. (1993),“Cointegration Tests of Purchasing Power Parity : the Case of Swiss Exchange Rates," Journal of International Money and Finance, Vol. 12, pp. 46-61. 
Table 1

Unit Root Tests for Nominal Exchange Rate and Price Levels

\begin{tabular}{|c|c|c|c|c|c|}
\hline \multicolumn{6}{|c|}{ Level } \\
\hline \multirow[t]{2}{*}{ Variable } & $\ln E$ & $\ln W P I$ & $\ln W P I^{*}$ & $\ln C P I$ & $\ln C P I^{\circ}$ \\
\hline & -0.93941 & -1.6104 & -0.00234 & 1.4516 & -1.6834 \\
\hline \multicolumn{6}{|c|}{ First Difference } \\
\hline \multirow[t]{2}{*}{ Variable } & $\ln E$ & $\ln W P I$ & $\ln W P I^{*}$ & $\ln C P I$ & $\ln C P I^{*}$ \\
\hline & -3.747 & -4.0775 & -5.937 & -7.0238 & -5.1668 \\
\hline
\end{tabular}

Notes : The critical value at the $95 \%$ significance level is -3.45 for $N=100$ (Fuller 1976, p.373).

Table 2

Johansen Maximum Likelihood Procedure ( $\operatorname{lnE}$, WPI, WPI* )

Cointegration LR Test Based on Maximal Eigenvalue of the Stochastic Matrix

\begin{tabular}{cccc}
\hline Null & Alternative & Statistic & $95 \%$ Critical Value \\
\hline $\mathrm{r}=0$ & $\mathrm{r}=1$ & 18.2347 & 21.0740 \\
$\mathrm{r}<=1$ & $\mathrm{r}=2$ & 6.4360 & 14.9000 \\
$\mathrm{r}<=2$ & $\mathrm{r}=3$ & 4.2808 & 8.1760 \\
\hline
\end{tabular}

Johansen Maximum Likelihood Procedure ( $\operatorname{lnE}, \mathrm{CPI}, C P I^{*}$ ) Cointegration LR Test Based on Maximal Eigenvalue of the Stochastic Matrix

\begin{tabular}{cccc}
\hline Null & Alternative & Statistic & 95\% Critical Value \\
\hline $\mathrm{r}=0$ & $\mathrm{r}=1$ & 18.5323 & 21.0740 \\
$\mathrm{r}<=1$ & $\mathrm{r}=2$ & 11.4005 & 14.9000 \\
$\mathrm{r}<=2$ & $\mathrm{r}=3$ & 5.4206 & 8.1760 \\
\hline
\end{tabular}


Table 3

Cumulative Impulse Response Changes

$$
\begin{aligned}
& \Delta P_{1}=C_{11}(L) \varepsilon_{t}^{p}+C_{12}(L) \varepsilon_{\imath}^{e}+C_{13}(L) \varepsilon_{l}^{p^{*}} \\
& \Delta e_{1}=C_{21}(L) \varepsilon_{1}^{p}+C_{22}(L) \varepsilon_{f}^{e}+C_{23}(L) \varepsilon_{l}^{p^{*}} \\
& \Delta P_{1}^{*}=C_{31}(L) \varepsilon_{1}^{p}+C_{32}(L) \varepsilon_{1}^{e}+C_{33}(L) \varepsilon_{f}^{p^{*}}
\end{aligned}
$$

$$
\begin{gathered}
{\left[\begin{array}{lll}
C_{11} & C_{12} & C_{13} \\
C_{21} & C_{22} & C_{23} \\
C_{31} & C_{32} & C_{33}
\end{array}\right]=\left[\begin{array}{ccc}
1.7726 & 0.09293 & 0.005026 \\
0.12405 & 1.09206 & -0.4756 \\
0.5096 & -0.1907 & 1.432
\end{array}\right]} \\
\Delta R_{t}=-1.13 \varepsilon_{t}{ }^{P}+0.804 \varepsilon_{t}{ }^{\circ}+0.9513 \varepsilon_{i}^{p^{\circ}}
\end{gathered}
$$

Table 4

Unit Root Test for Variable Series in Equation (4)

\begin{tabular}{cccc}
\hline $\ln \mathrm{R}$ & $\left(\ln A_{n}-\ln A_{T}\right)$ & $\left(\ln A_{n}^{*}-A_{i}^{*}\right)$ & $\left(\ln E+\ln \left(\frac{W^{*}}{A_{t}^{*}}\right)-\ln \left(\frac{W}{A}\right)\right)$ \\
-1.233 & -1.868 & -0.398 & -0.586 \\
\hline$\Delta \ln R$ & $\Delta\left(\ln A_{n}-\ln A_{T}\right)$ & $\Delta\left(\ln A_{n}^{*}-A_{t}^{*}\right)$ & $\Delta\left(\ln E-\ln \left(\frac{W^{*}}{A_{t}^{*}}\right)-\ln \left(\frac{W}{A}\right)\right)$ \\
-6.92 & -9.80 & -11.53 & -6.80 \\
\hline
\end{tabular}

Notes: Real exchange rates are denominated in WPI. 
Table 5

Johansen Maximum Likelihood Procedure

Cointegration LR Test Based on Maximal Eigenvalue of the Stochastic Matrix

\begin{tabular}{cccc}
\hline Null & Alternative & Statistic & $95 \%$ Critical Value \\
\hline $\mathrm{r}=0$ & $\mathrm{r}=1$ & 57.3693 & 27.0670 \\
$\mathrm{r}<=1$ & $\mathrm{r}=2$ & 20.1958 & 20.9670 \\
$\mathrm{r}<=2$ & $\mathrm{r}=3$ & 5.1362 & 14.0690 \\
$\mathrm{r}<=3$ & $\mathrm{r}=4$ & $.8724 \mathrm{E}-3$ & 3.7620 \\
\hline
\end{tabular}

Cointegration LR Test Based on Trace of the Stochasic Matrix

\begin{tabular}{cccc}
\hline Null & Alternative & Statistic & $95 \%$ Critical Value \\
\hline $\mathrm{r}=0$ & $\mathrm{r}>=1$ & 82.7022 & 47.2100 \\
$\mathrm{r}<=1$ & $\mathrm{r}>=2$ & 25.3329 & 29.6800 \\
$\mathrm{r}<=2$ & $\mathrm{r}>=3$ & 5.1371 & 15.4100 \\
$\mathrm{r}<=3$ & $\mathrm{r}=4$ & $.8724 \mathrm{E}-3$ & 3.7620 \\
\hline
\end{tabular}


Table 6

Estimates of Time-Specific Effect

$$
\begin{aligned}
& \ln R_{T}=Q_{T}+\alpha\left(\ln A_{n}-\ln A_{t}\right)_{T}-\beta\left(\ln A_{n}^{*}-\ln A_{t}^{*}\right)_{T}+\left(\ln E+\ln \frac{W^{*}}{A_{1}^{*}}-\ln \frac{W}{A_{t}}\right)_{T} \\
& Q \\
& 0.40 \quad(0.0683) \\
& 0.47 \quad(0.0713) \\
& 0.53 \quad(0.0736) \\
& 0.51 \quad(0.0766) \\
& 0.71 \quad(0.0766) \\
& 0.92(0.0765) \\
& 1.11 \quad(0.0814) \\
& 1.36(0.0846) \\
& 1.52(0.0902) \\
& 1.57 \quad(0.0968) \\
& 1.78 \quad(0.1090) \\
& 1.85(0.1250) \\
& 1.94(0.1340) \\
& 2.08 \quad(0.1450)
\end{aligned}
$$

Notes: Standard error in parentheses. 
Figure 1

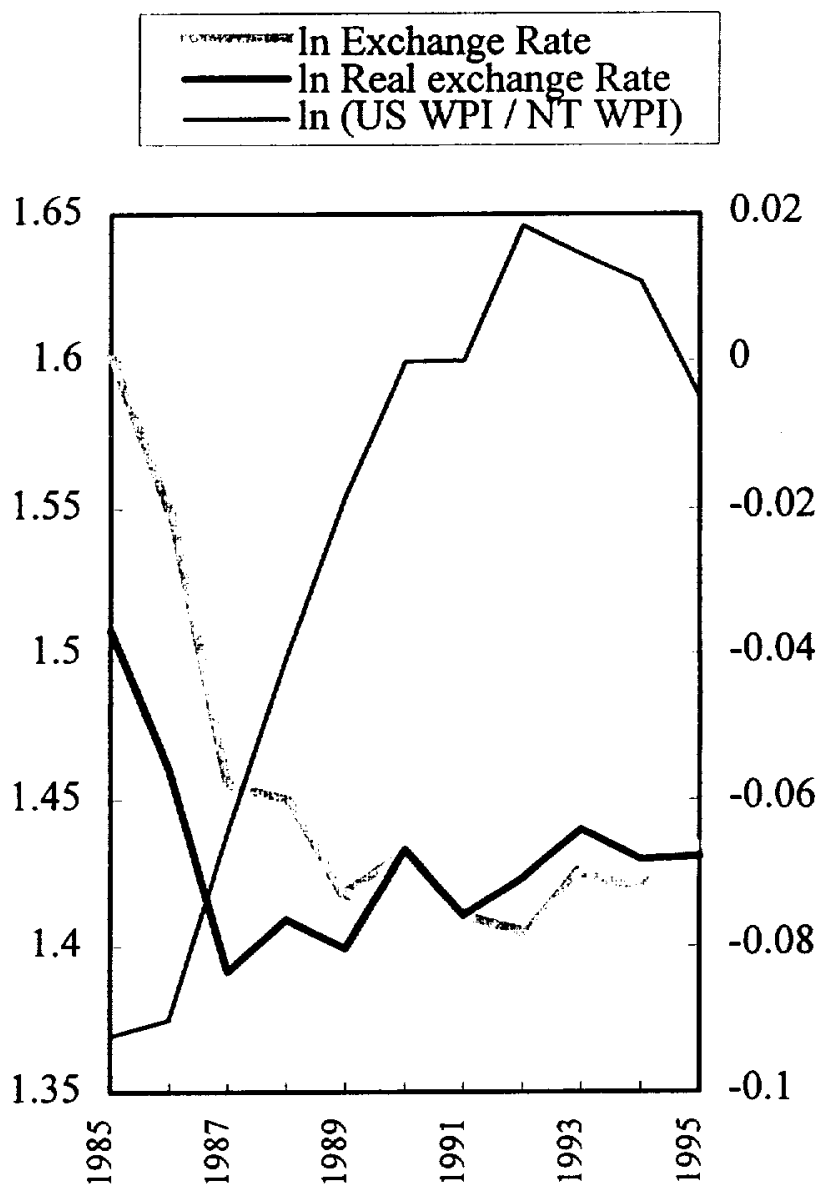


Figure 2

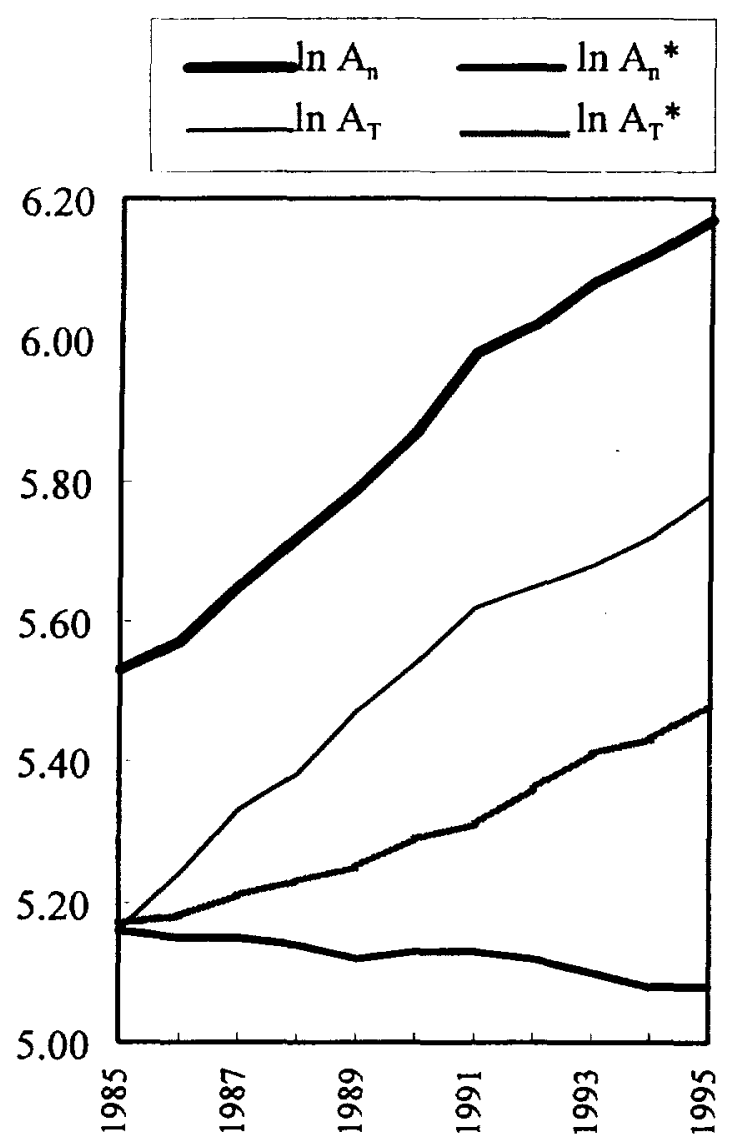

An : Productivity in non-traded sector in Taiwan.

$\mathrm{An}^{*}$ : Productivity in non-traded sector in the U.S.

AT : Productivity in traded sector in Taiwan.

AT*: Productivity in traded $^{*}$ sector in the U.S. 
Figure 3

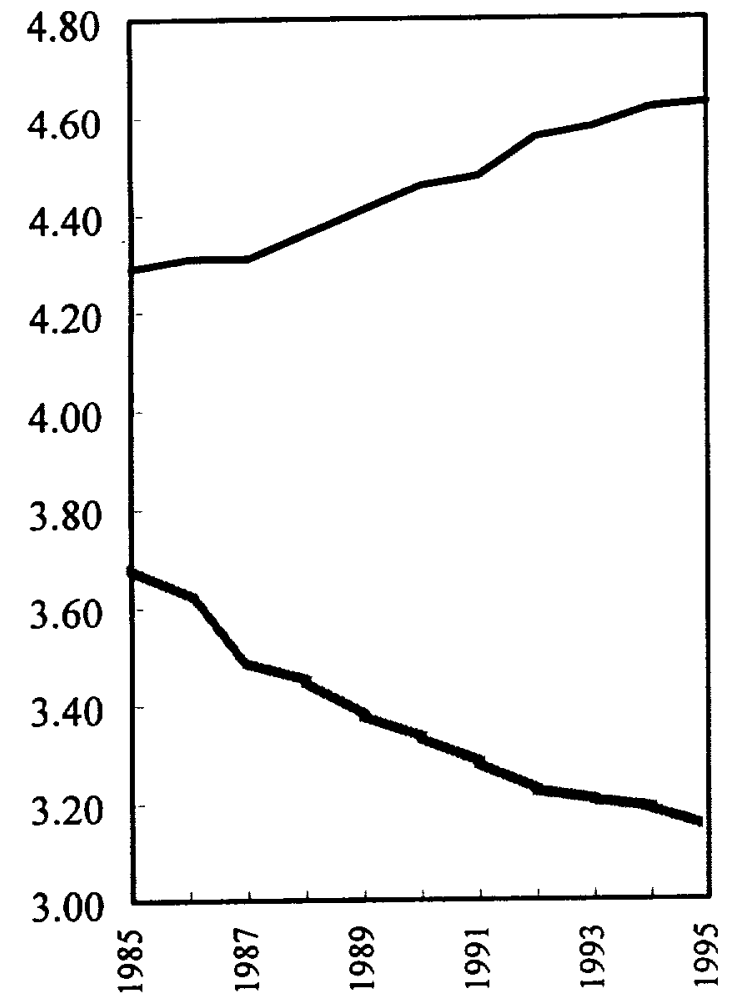

changes in unit labor cost in the U.S.

changes in unit labor cost in Taiwan. 